Boletín de la Sociedad Geológica Mexicana

VOLUMEN 66, NÚM. 1, 2014, P. 199-214

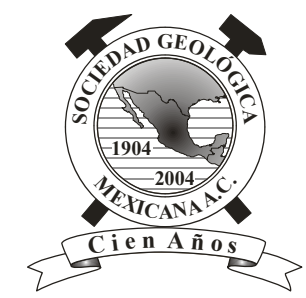

\title{
Filamentous micro-organisms, inorganic inclusions and pseudo-fossils in the Miocene amber from Totolapa (Chiapas, Mexico): taphonomy and systematics
}

\author{
Gérard Breton ${ }^{1}$, María de Lourdes Serrano-Sánchez², Francisco J. Vega ${ }^{3, *}$ \\ ${ }^{1} 6$ rue des Réservoirs, F-76600 Le Havre, and UMR CNRS 6118 Géosciences, Université de Rennes I, France. \\ ${ }^{2}$ Posgrado en Ciencias de La Tierra, Instituto de Geología, UNAM, Ciudad Universitaria, Coyoacán, México DF 04510, Mexico. \\ ${ }^{3}$ Instituto de Geología, UNAM, Ciudad Universitaria, Coyoacán, México DF 04510, Mexico. \\ *vegver@unam.mx
}

\begin{abstract}
The amber from Totolapa (Chiapas, Mexico) is thought to have been secreted by Hymenea sp. during Early to Middle Miocene time, and then reworked during Pleistocene ash flow events. Most of this amber is preserved within pyroclastic sediments. Peripheral layers of amber pieces from Totolapa yield a wealthy microflora including 1) one morpho-species of filamentous bacterium, 2) a sheathed bacterium Melanothrix mexicana gen. sp. nov., 3) five morpho-species of Actinobacteria (actinomycetes), Scopaeopsis verticillata gen. sp. nov., Thermomonosporopsis chiapasensis sp. nov., and three left in open nomenclature, and 4) diverse fungal mycelia. Melanothrix mexicana, Thermomonosporopsis chiapasensis, Actinobacteria gen. A sp. A and fungi were early colonizers of the fluid bark exudates of resin, and they grew either superficially or centripetally, as observed in modern resinicolous biota.
\end{abstract}

Keywords: Amber, prokaryote, fungi, new taxon, Miocene, Mexico.

\section{Resumen}

Se considera que el ámbar de Totolapa (Chiapas, México) fue secretado por Hymenea sp. durante el Mioceno Temprano a Medio, y que posteriormente fue retrabajado por flujos de ceniza durante el Pleistoceno. Gran parte de este ámbar está preservado en flujos piroclásticos. Las capas superficiales de las piezas de ámbar de Totolapa producen una rica microflora, incluyendo 1) una morfo-especie de bacteria filamentosa; 2) la bacteria envainada Melanothrix mexicana gen. sp. nov.; 3) cinco morfo-especies of Actinobacteria (actinomycetes), Scopaeopsis verticillata gen. sp. nov., Thermomonosporopsis chiapasensis sp. nov., y tres en nomenclatura abierta; y 4) diversos micelios fungales. Melanothrix mexicana, Thermomonosporopsis chiapasensis, Actinobacteria gen. A sp. A y los fungi fueron colonizadores iniciales de la resina de fluidos exudados de corteza, y crecieron ya sea de manera superficial o centripeta, como se observa en biota resinícola moderna.

Palabras clave: Ámbar, procaryote, fungi, nuevo taxón, Mioceno, México. 


\section{Introduction}

Ambers have long drawn the attention of paleontologists for their well preserved and diverse animal or vegetal fossils. Most of these fossils are continental, far less well represented in the fossil register than aquatic, mainly marine, organisms. In ambers, terrestrial arthropods are the most frequent, searched for and studied. Paleontologists used to pay more attention to macrofauna preserved in amber, especially insects, than to micro-organisms (see for instance Poinar, 1992, 1994) although pollen, fungi mycelia, algal filaments, bacteria or spores have been known for a long time (Göppert and Berendt, 1845; Göppert and Menge, 1883; Galippe, 1920; Blunck, 1929). The excellent preservation of micro-organisms has allowed, more recently, descriptive and analytic studies of this type of material (Waggoner and Poinar, 1992; Poinar et al., 1993; Waggoner, 1993, 1994a, b, 1996; Kohring, 1995; Waggoner, 1996, Breton et al., 1999; Schmidt et al., 2004; Breton and Tostain, 2005; Schmidt and Schäfer, 2005; Schmidt, 2006; Schmidt et al., 2006; Breton, 2007; Schmidt and Dilcher, 2007; Schmidt et al., 2007, 2008; Girard, 2009; Girard et al., 2009a, b, c, d; Breton, 2010; Girard, 2010; Girard and Adl, 2011; Girard et al., 2011; Breton,2012; Girard, 2012; Saint Martin et al., 2012; Breton et al., 2013; Saint Martin et al., 2013). The latest studies have shown that many of these micro-organisms were resinicolous organisms that grew in resin, and soon after its production, colonized the exudate and embedded themselves within resin in a quite different way than trapped micro-organisms (pollen for instance) or macro-organisms (insects for instance). Moreover, the taphonomic significances of both processes, enhanced by the studies on modern resin exudates, are quite different (Rikkinen and Poinar, 2000; Rikkinen, 2003; Breton, 2007; Brasier et al., 2009; Girard et al., 2009a,d; Beimforde and Schmidt, 2011; Breton, 2011, 2012).

The fungi and prokaryotes are now well known from mid-Cretaceous (e.g. Schmidt and Schäfer, 2005; Girard et al., 2009a), Upper Cretaceous (e.g. Saint Martin et al., 2012, 2013), and Eocene amber (e.g. Breton, 2012) and in modern resins (e.g. Beimforde and Schmidt, 2011).This work intends to begin to fill the chronological gap between Eocene amber and modern resins, with the objective of making a posterior review of the evolution of resinicolous microfloras from Cretaceous to present (Breton, 2012). It also intends to get new insight on the taphonomic topic of trapping $v s$. colonization of fluid resin exudates, and to provide a description of the Mexican amber microorganisms, which remain poorly studied. All described micro-organisms are associated with trapped macro-biota: bacteria (Poinar, 1992, 1999), fungi on a dicot petal (Poinar, 2003), pathogenic micro-organisms on insects (Poinar and Poinar, 2005), and micro-organisms (bacteria) associated with termites (Veiga Crespo et al., 2007).

\subsection{Geologic context}

Although most famous amber-bearing outcrops in Chiapas are those nearby Simojovel, a series of new locations in Chiapas are informally known (SolórzanoKraemer, 2007; 2010). In these new localities, Totolapa amber is becoming more frequent among specialists interested in the study of amber inclusions (Azar et al., 2010; Durán-Ruiz et al., 2013). Totolapa is found $40 \mathrm{~km}$ SE of Chiapa de Corzo (Figure 1) and about $50 \mathrm{~km} \mathrm{SE}$ of Tuxtla Gutiérrez, in what is geologically known as the Chiapanecan Volcanic Arc (Mora et al., 2007; 2012). Occurrence of amber near Totolapa was formally reported based on the archaeological usage (Bryant, 1983). The author mentions that the amber has a volcanic ash cortex. This observation is very important, since most of the amber pieces are relatively rounded and medium sized (about 3 $\mathrm{cm}$ in diameter), have a dark red colour and are included in pyroclastic sediments that also contain carbonized wood and lignitic matter. Occasional reworked marine gastropods and bivalves are also found included in the ash flow, which was deposited during the Pliocene-Pleistocene volcanic event (Damon and Montesinos, 1978). The closest volcanic dome to the Totolapa amber-bearing deposits is that of Venustiano Carranza, with a middle Pleistocene age (0.225 Ma, see Mora et al., 2012). The pyroclastic sediments are underlain by dark gray fine sandstones and mudstones that crop out at the base of the sequence, on sides of the Totolapa River (Figure 2). This unit is lithologically similar to the Simojovel Formation, and includes marine molluses, corals as well as amber pieces. The marine fauna has not been formally reported but it resembles that of the Miocene amber-bearing units near Simojovel, dated as Early to Middle Miocene (Solórzano-Kraemer, 2007, 2010; Vega et al., 2009a; Perrilliat et al., 2010). Durán-Ruiz et al. (2013) suggest that the amber-bearing Miocene Mazantic Shale and Balumtum Sandstone crop out at Río Salado and Río Yalbantuc, near Totolapa. Thus, amber pieces included in the pyroclastic sequence near Totolapa seem to have been exhumed and reworked during one or several ash flow events that took place during the middle Pleistocene, but the age of the amber remains as Miocene.

\section{Material and methods}

Several authors (e.g. Girard et al., 2009b; Beimforde and Schmidt, 2011) highlighted the possible contamination of amber pieces by recent organisms, and Girard et al. (2009b) developed a decontamination protocol. Though one of us (GB) took part in this development, we did not apply the Girard et al.'s decontamination protocol to the Totolapa amber pieces for the following reasons. The contamination of pieces of mid-Cretaceous amber by diatoms was significant when amber was collected in littoral 
or freshwater settings, but not in mountains settings (Girard, 2010). Moreover, we have not observed any diatoms in the studied samples from Totolapa. When the amber pieces are contaminated by fungi or other filamentous organisms, they grow upon the surface of the amber (Beimforde and
Schmidt, 2011), especially in the cracks (Breton, 2012), but do not penetrate inside the amber. To prevent this superficial contamination, all the amber pieces have been washed in an ultrasonic cleaner before thin flakes were removed from the surface. We have not found any filamentous organism upon
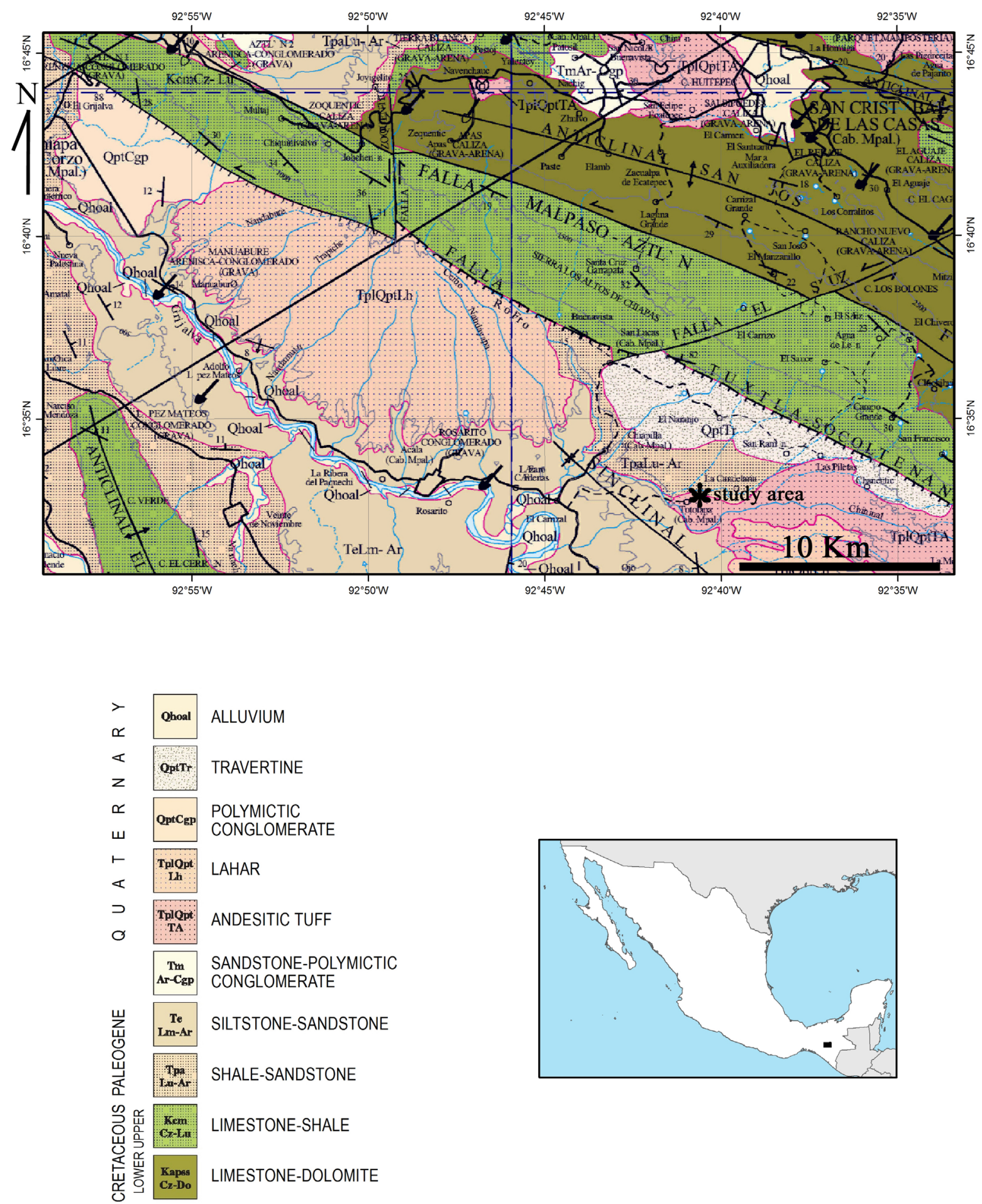

Figure 1. Geologic map of central portion of Chiapas, Mexico. Asterisk indicates outcrop near Totolapa, where the Miocene reworked amber pieces here studied were collected in Pleistocene (TplQptTA) andesitic tuff. Modified from Servicio Geológico Mexicano (2005) 


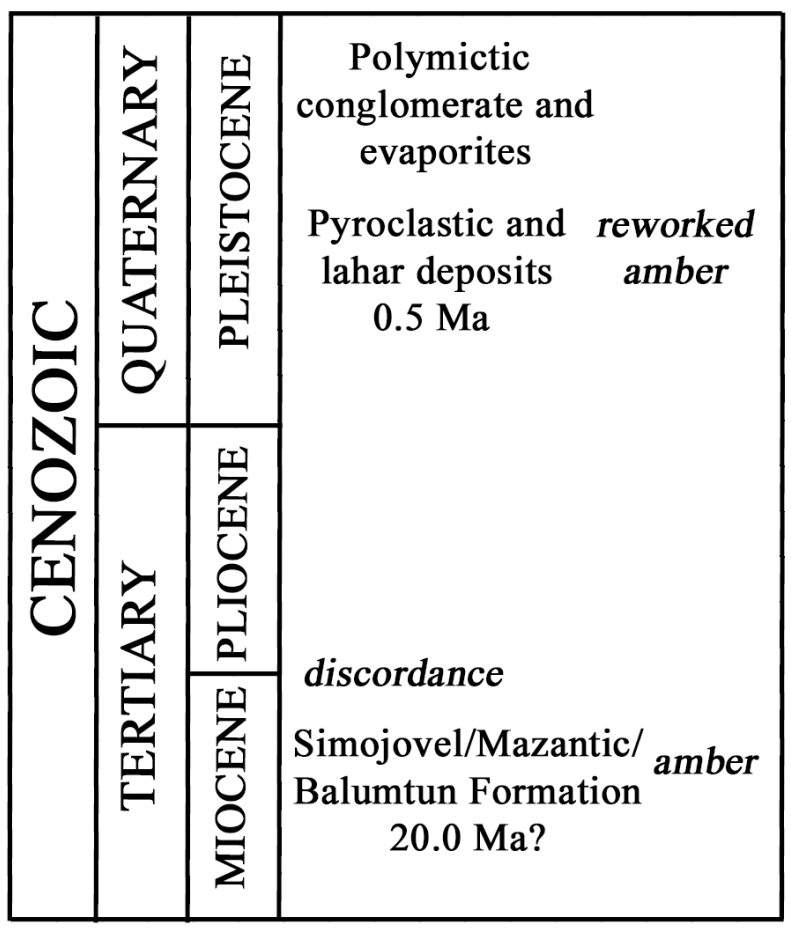

Figure 2. Lithostratigraphic units that crop out at the study area.

the surface or within the cracks. Moreover, each isolated inclusion was carefully examined under DIC illumination, in order to ascertain it was not included in a healed fissure. Any dubious case would have been rejected.

Nine rough amber pieces from Totolapa (Chiapas, Mexico), numbered from 1 to 9, were selected. Eight were retained for study; the ninth was already too highly polished, and no longer had any rough surfaces. Very thin flakes of the superficial amber were removed from the pieces, when possible parallel or perpendicular to the surface, and mounted in Canada balsam. The cover glass is propped up with two lateral cover glasses, in order to avoid crushing the thickest amber flakes since Canada balsam shrinks when drying. This method had previously been used and compared with traditional petrographic thin sections, either with or without cover glass (Breton and Tostain, 2005; Breton, 2007, 2011, 2012). It appears that the method used herein does not introduce any bias on the micro-organisms assemblage.

Microscopic slides are numbered 1-8; two preparations were made for amber pieces 5 and 6 , and were numbered $5 \mathrm{~A}$, 5B, and 6A, 6B, respectively. Preparations contain 8 to 15 flakes each. They were dried during one week at $50-60{ }^{\circ} \mathrm{C}$, and were then studied under transmitted light (bright field $\mathrm{BF}$ ), incident light if necessary (IL), polarized light (PL) and, mainly, Nomarski Differential Interference Contrast (DIC) illumination of a NS 400 Nachet microscope. To compensate for the very weak field depth, specially with high magnifications, a series of images at different focuses were taken and stacked under Zerene Stacker (C) program in order to get a final large field depth zetagraphy, denoted
ZS in the legends of the figures. When the same operation is made without the help of Zerene Stacker, building up a mosaic of elements of pictures taken at different focuses is denoted as "mosa". The figures are touched up, scaled and composed under Photoshop Elements $\mathbb{C}$. For more information, see Breton (2012).

\subsection{Remarks on the systematics of micro-organisms}

The systematics of modern micro-organisms, prokaryotes and fungi, is mainly based on culture and biochemical features. Morphology is of little use for living microorganisms. In paleontology, however, morphologic criteria are the only information available. The new taxa that we describe herein are thus morpho-genera and morpho-species. Sometimes, characters of the life cycle (e.g. sporulation) allow a more confident or plausible placement within the taxonomy of modern organisms, but such a placement is "usually tentative at best" (Waggoner, 1993).

\subsection{Abbreviations}

BF: Bright field diascopic illumination. IL: incident episcopic illumination. DIC: Nomarski Differential Interference Contrast illumination. ZS: zetagraphy. Mosa: mosaic of pictures.

\subsection{Repository}

The slides in this study are deposited at the Colección Nacional de Paleontología, Instituto de Geología, UNAM, under acronym IGL-LPB and are numbered as follows.

\begin{tabular}{|c|c|c|}
\hline \multicolumn{2}{|c|}{ Slide Collection number } & Containing the type of \\
\hline 1 & IGM-LPB 1111 & $\begin{array}{l}\text { Melanotrix mexicana gen. sp. nov. } \\
\text { Figure } 3.7 \text {. }\end{array}$ \\
\hline 2 & IGM-LPB 1112 & $\begin{array}{l}\text { Scopaeosis verticillata gen. sp. nov. } \\
\text { Figure } 4.9,4.10 .\end{array}$ \\
\hline 3 & IGM-LPB 1113 & Scopaeosis verticillata gen. sp. nov. \\
\hline 4 & IGM-LPB 1114 & Scopaeosis verticillata gen. sp. nov. \\
\hline $5 \mathrm{~A}$ & IGM-LPB 1115 & Scopaeosis verticillata gen. sp. nov. \\
\hline 5B & IGM-LPB 1116 & Scopaeosis verticillata gen. sp. nov. \\
\hline $6 \mathrm{~A}$ & IGM-LPB 1117 & Scopaeosis verticillata gen. sp. nov. \\
\hline 6B & IGM-LPB 1118 & Scopaeosis verticillata gen. sp. nov. \\
\hline 7 & IGM-LPB 1119 & Scopaeosis verticillata gen. sp. nov. \\
\hline 8 & IGM-LPB 1120 & $\begin{array}{l}\text { Thermomonosporopsis chipasensis sp. } \\
\text { nov., Figure } 4.4 \text {. }\end{array}$ \\
\hline
\end{tabular}

\section{Results}

\subsection{Description of amber pieces}

Pieces $1-8$ all have a complete or partial original rough surface. The gangue is a more or less consolidated slightly clayey gypsum sand, with tiny wood fragments. Piece 1 is dark brown, the surface is finely and irregularly cracked. Piece 2 is honey-yellow to dark brown with layers of dull, 
opaque, caramel-coloured resin. Piece 3 is as 1, gypsum in the gangue. Piece 4 is a worked and polished piece which displays six surfaces of very thin flows of resin, and two oblique cracks (Figure 3.1). Piece 5 is the biggest, slightly flattened, one face convex (5A), the other irregularly flat, thought to have casted the substrate (5B). The surface is finely cracked, dark honey to brown coloured. Piece 6 is irregularly shaped, the gangue is a clayey gypsum sand: $6 \mathrm{~A}$ a dark coloured cortex, flakes taken from depressions of the surface, $6 \mathrm{~B}$ on rounded surfaces of the amber piece. Piece 7 is composed of two exudates stuck together, the amber of the smallest a bit lighter; amber flakes removed from the boundary between the two exudates (Figure 3.2). Although piece 8 is partially polished, its flakes could be removed from concavities preserving the original surface of the exudate. Piece 9 is too highly polished to allow making a sample preparation. No macro-organisms were found in these amber pieces.

Locally, amber flakes illuminate under polarized light and then display a grey or yellow colour, but most of the amber flakes do not.

\subsection{Pseudo-fossils and inorganic inclusions}

Pseudo-fossils were first introduced by Hofmann (1971); Häntzschel (1975, p. W168) gives the following definition: "This chapter [pseudo-fossils] deals with structures that in one way or another are suggestive of being "fossils" but are certainly or most probably of inorganic origin." Pseudofossils are few in Totolapa amber, probably because it is much less brittle than other ambers (a property that allows its use for jewellery). Pectinate cracks can be observed near pyrite crystals (Figure 3.3, blue arrow, amber piece 7). Very aesthetic break surfaces display a fan-like repeated sinusoidal pattern, well enhanced by DIC-illumination (Figure 6.8). Amber piece 2 contains typical pseudo-protists (sensu Girard et al., 2011), 5-80 $\mu \mathrm{m}$ in diameter (Figure 3.5). Such inclusions are very abundant in Cretaceous ambers from France, and Girard (2010) and Girard et al. (2011) demonstrated they are pseudo-fossils. The pseudoprotists of the amber piece 2 from Totolapa are ovoid, have a distinct membrane-like border, and their content ranges from sub-hyaline to dark opaque. Some display a brown foamy content (type B of Girard, 2010).

A group of cubic and truncated octahedral crystals of pyrite measuring $1-8 \mu \mathrm{m}$ occur in amber piece $5 \mathrm{~A}$, and elongated groups of framboidal pyrite, together with $5 \mu \mathrm{m}$ cubic crystals, in amber piece 7. This pyrite is black and opaque in transmitted light, and yellow and reflective in incident light (Figure 3.3,3.4). The characteristic brass colour of pyrite in incident light is here modified by the inclusion in amber, but the high reflectivity together with its cubic and octahedral shape confirm the identity of the mineral.

\section{Systematic paleontology (by Gérard Breton)}

\section{Bacteria}

Class Proteobacteria Woese et al., 1990

Burkholderiales Garrity et al., 2005

Morpho-genus Melanothrix gen. nov.

Etymology. Greek roots melan: black, and thrix: thread, the appearance of this bacteria being that of black threads. Gender feminine.

Type species. Melanothrix mexicana sp. nov, by monotypy.

Diagnosis. Trichome $0.6-0.8 \mu \mathrm{m}$ thick, straight, branching often at $90^{\circ}$ but sparsely branched, stained and encrusted by black matter, often regularly $1.5 \mu \mathrm{m}$ in diameter but ranging from 1.2 up to $2-3 \mu \mathrm{m}$, rarely $5 \mu \mathrm{m}$. Trichome irregularly surrounded by a sheath $8-15-28$ $\mu \mathrm{m}$ in diameter, sometimes tapering, sometimes vanishing. Black granules $0.2-1.5 \mu \mathrm{m}$, rarely up to $3 \mu \mathrm{m}$, more or less dense, often absent, concentrate in more or less long cylinders, within the sheath when visible, and especially in its internal half. Black granules can be coalescent with the crust surrounding the trichome.

Differences with other taxa. Three fossil sheathed bacteria are known: Sphaerotilus spp. and Leptotrichites resinatus Schmidt in Schmidt and Schäfer, 2005, both Burkholderiales, and the cyanobacterium Palaeocolteronema cenomanensis Breton and Tostain, 2005. Sphaerotilus spp. are less branched and have a hyaline, regular sheath devoid of granulations. Leptotrichites resinatus has a smaller sheath than Melanothrix, and its sheath, if "dusty" or "rough" contains much smaller granulations. Palaeocolteronema cenomanensis has dichotomic branching, its sheath is hyaline, devoid of granulations and of a smaller diameter; it can bear hormogonias. All three taxa, as well as other unnamed sheathed filaments are to be found in French and Spanish Cretaceous ambers (Breton and Tostain, 2005; Girard, 2010; Saint Martin et al., 2012; Breton, 2012; Breton et al., 2013; Saint Martin et al., 2013).

Geographical and stratigraphic distribution. These data are restricted to the material described herein: Miocene amber of Chiapas, Mexico.

Morpho-species Melanothrix mexicana sp. nov. Figures 3.6-3.10

Etymology. From Mexico.

Holotype. The specimen figured as Figure 3.7, IGMLPB 1111.

Geographical and stratigraphic origin of the holotype. Amber of Totolapa, Chiapas, Mexico. Miocene. Material. Amber pieces 1, 4, 6A.

Diagnosis. As for the genus.

Description. The trichome itself is very rarely bare, 

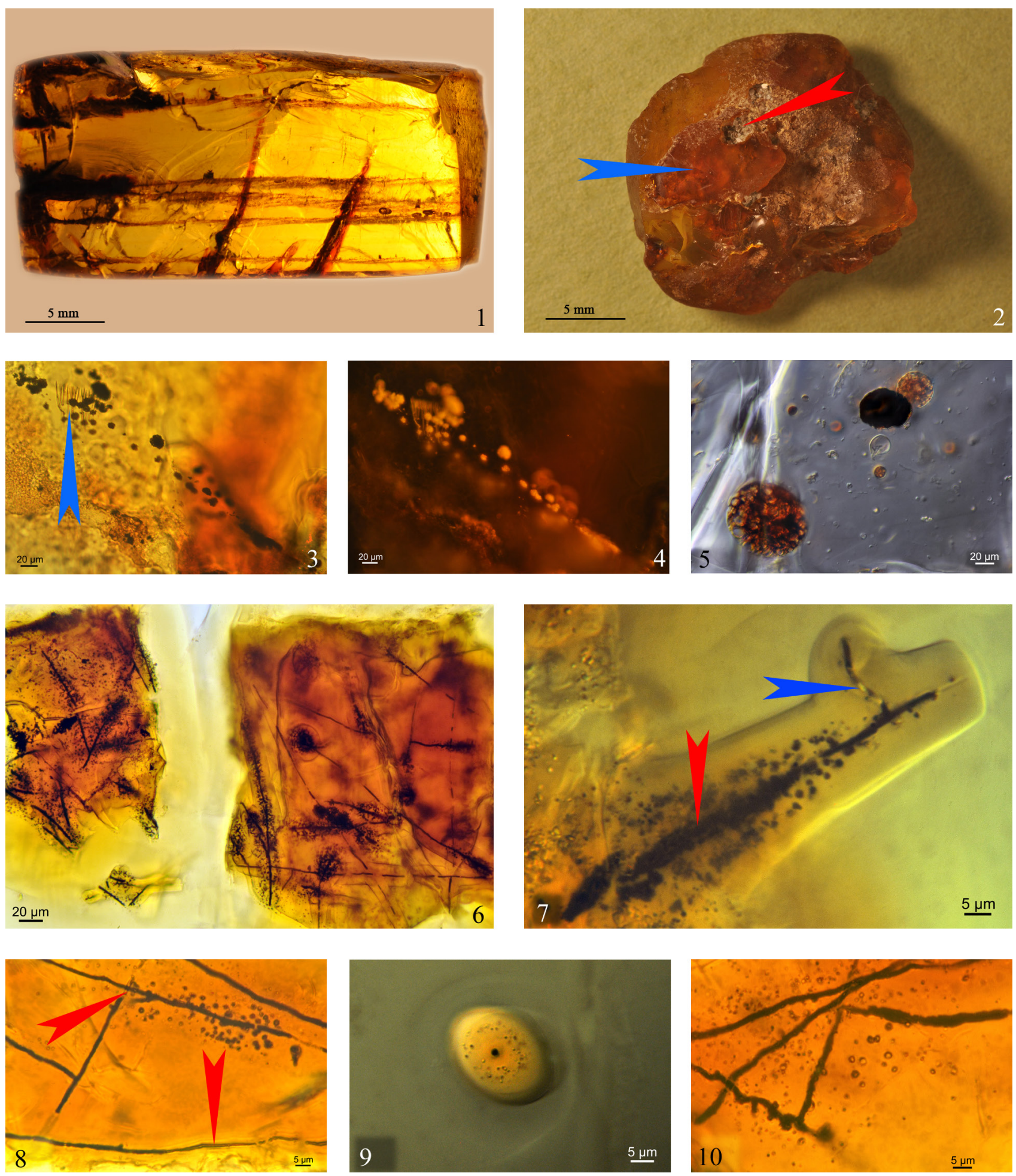

Figure 3. 1. Piece 4. BF. 2. Piece 7. Red arrow: remains of gypsum-rich sand. Blue arrow: boundary between the main exudate and the small one, where flakes have been taken. 3. Piece 7. Pyrite crystals (black). Blue arrow: a pectinate crack (pseudo-fossil). BF. 4. As Figure 3.3 but IL. 5. Piece 2. Pseudoprotists. DIC. ZS. 6-10. Melanothrix mexicana gen. sp. nov. 6. Piece 1. Overall view. BF. ZS. 7. Piece 1. Holotype. IGM-LPB 1111. Trichome, coated with black matter, locally thickened (red arrow), perpendicular branching, rare parts of the trichome devoid of coating (blue arrow), black granules and sheath. DIC. ZS. 8. Piece 6A. Perpendicular branching, cylindrical "cloud" of granules. Red arrow: bare trichome. BF. ZS. 9. Piece 1. Cross-section. DIC. 10. Piece 6A. Irregular course of a trichome, and thickening of the black layer. BF. 
and then light coloured (Figure 3.7, blue arrow; Figure 3.8, red arrow). In preparation 6A, a very short part of a bare trichome shows what is here interpreted as three cells. The diameter of the trichome is $0.7 \mu \mathrm{m}$, and the length of the cells $1.7 \mu \mathrm{m}$ (cells 2.5 times longer than wide). In no other place are the cells visible. On one hand, there are very few places where the trichome is bare. On the other hand, cell borders may be invisible for taphonomic reasons. Thus, we have not integrated the dimensions of the cells in the diagnosis because we have not been able to confirm this observation. The trichome is nearly always straight (Figure 3.8), rarely irregular (Figure 3.10), for instance helicoidally coiled. It looks nearly always black, because the cell wall is incrusted by black matter (or re-covered by a layer). This layer sometimes thickens up to $3-4 \mu \mathrm{m}$ (Figure 3.7). Branching is rare, often perpendicular (Figure 3.7, 3.8). The sheath is cylindrical (or elliptical in cross-section) (Figure 3.7-3.9), hyaline with the exception of black granules $0.5-1.5-3.0$ $\mu \mathrm{m}$. Some granules are not totally black and opaque in bright field, but are brown (Figure 3.9). The "cloud" of granules is more or less dense, and forms a cylinder that surrounds the trichome (Figure 3.6-3.8). The diameter of the cylinder is $10-35 \mu \mathrm{m}$ and in length ranges from a few $\mu \mathrm{m}$ to $250 \mu \mathrm{m}$.

The filaments of Melanothrix mexicana run roughly parallel to the surface of the amber piece at a depth of 30 to $200 \mu \mathrm{m}$. When compared to living sheathed bacteria, the black matter of the granules and the coat of the trichome could be made up of iron oxides, but this cannot be proved here. The brown granules could be made of siderite. Therefore, the co-occurrence of these trichomes with pyrite, as in $6 \mathrm{~A}$, favours the hypothesis of iron oxides and carbonate.

Comparison with other taxa, geographical and stratigraphic distribution. As for the genus.

\section{Class Actinobacteria Stackebrandt et al., 1997 \\ Order Actinomycetales Buchanan, 1917 \\ Family Thermomonosporaceae Rainey et al. in Stackebrandt et al., 1997}

\section{Morpho-genus Thermomonosporopsis Breton, 2010}

Diagnosis from Breton, 2010, emended. Pigmented mycelium several times branched, branches straight. Transparent mycelium more or less regularly several times branched, branches straight, branching often dichotomous at $60^{\circ}$. Sporophores on both mycelia, carried by a peduncle branched or not. Sporifere branches crisp, branched, building up distally a dense clump, spherical, hemispherical, umbrella shaped, or cylindrical around the apex of the axis. Spores rounded, light coloured, $0.3-0.5 \mu \mathrm{m}$ in diameter. The pigmented mycelium rarely fragments into more or less long rods; transparent mycelium frequently fragments into rods or cocci. Uncommon endosporulation mainly concerns the transparent mycelium.

Remarks. Aerial and substrate mycelium of living actinomycetes are distinguished in culture (Vobis in Miyadoh, 1997, p. 181). As it is impossible to correlate either mycelia with those observed in amber, Breton (2010) used the categories "robust mycelium" and "spindly mycelium" respectively for the pigmented and transparent filaments because he noticed a difference in diameter in the two known species. In the new species, described herein, there is no difference in diameter, so the categories retained for the emended diagnosis are not "aerial/substrate", nor "robust/spindly", but "pigmented/transparent". For more details, see Breton (2010, p. 6-7; 2012, p. 25-26, 76).

Included species. Thermomonosporopsis waggoneri Breton, 2010 (type species), Thermomonosporopsis tenuis Breton, 2010; Thermomonosporopsis chiapasensis sp. nov.

Geographical and stratigraphic distribution. Amber from the Eocene of France, and from the Miocene of Mexico.

Morpho-species Thermomonosporopsis chiapasensis sp. nov.

Figure 4.1-4.5

Etymology. From Chiapas state (Mexico).

Holotype. The specimen figured as Figure 4.4, IGMLPB 1120.

Geographical and stratigraphic origin of the holotype. Amber of Totolapa, Chiapas, Mexico. Miocene. Material. Amber pieces 6A, 6B, 7, 8 .

Diagnosis. A Thermomonosporopsis with the same diameter of hyphae $(1 \mu \mathrm{m})$ for the pigmented and transparent mycelium (Figure 4.1). Transparent branches bearing sporophores straight, few or not branched. Sporophores may be confluent (Figure 4.3). Pigmented mycelium irregularly branched, branching often lateral at $60^{\circ}$, rarely verticillate. Fragmentation of the pigmented mycelium into branched fragments (Figure 4.4). Distal chains of conidiospores form in the pigmented hyphae (Figure 4.5).

Description. The diameter of the hyphae is $c a .1 \mu \mathrm{m}$. Rarely, the diameter seems a little bigger for taphonomic reasons ("taphonomic enlargement" sensu Breton, 2012). The pigmented mycelium can break into branched fragments (Figure 4.4), and finally into rod-like fragments. Distal chains of conidiospores or endospores form on axial or lateral branches of the pigmented mycelium (Figure 4.5). One observation of a pigmented tuft thought to belong to this species shows a pigmented axis $20 \mu \mathrm{m}$ long, from which arises a first verticil of branched hyphae, $15 \mu \mathrm{m}$ in diameter, and a second one $12 \mu \mathrm{m}$ in diameter. Viewed from above, the transparent mycelium shows a sterile axis up to $40 \mu \mathrm{m}$ long, radiating, with lateral or dichotomous branching (Figure 4.3). Sporophores up to $20 \mu \mathrm{m}$ long, less branched, ended by a very dense, basically spherical clump of thin, much branched filaments carrying each a distal spore, $c a .0 .5 \mu \mathrm{m}$ in diameter. Sporophores are often profuse, and sporophores issued from neighbour hyphae can be confluent and form a continuous layer (Figure 4.2, viewed from above). Endosporulation occurs in the pigmented 

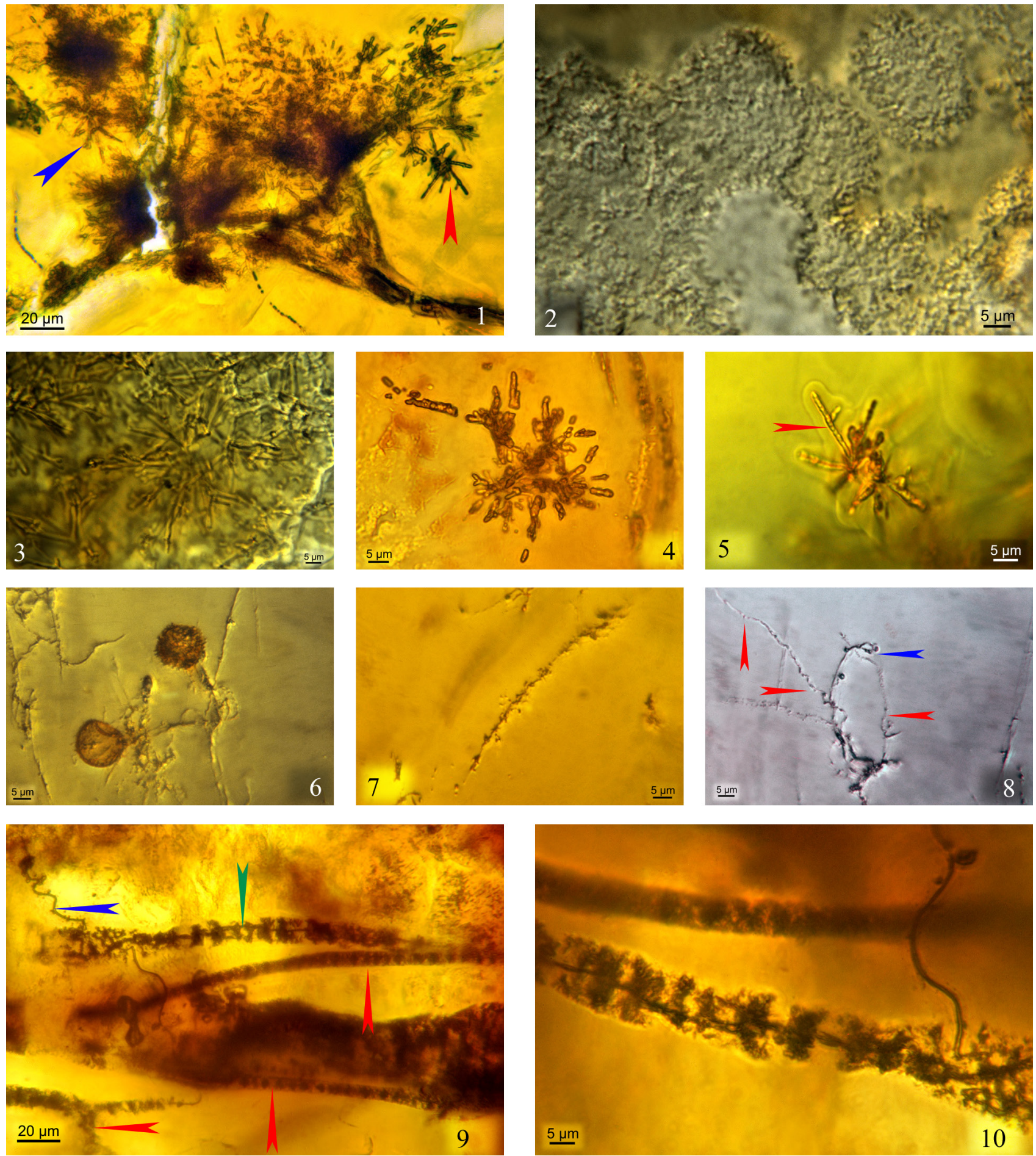

Figure 4. 1-4. Thermomonosporopsis chiapasensis sp. nov. 1. Piece 8. Overall view. Pigmented mycelium (red arrow) and transparent mycelium (blue arrow). BF. ZS. 2. Piece 7. Confluent sporophores issued from neighbour transparent hyphae, viewed from above. DIC. ZS. 3. Piece 7. Sterile transparent mycelium, viewed from above. DIC. ZS. 4. Piece 8. Holotype. IGM-LPB 1120. Pigmented mycelium breaking into branched or rod-like fragments. Note the possible endosporulation. BF. ZS. 5. Piece 8. Pigmented mycelium: endosporulation (red arrow). DIC. 6. ? Streptosporangium sp. Piece 2. Mycelium and two sporangia, empty (left) or spore-containing (right). DIC. ZS. 7, 8. ? Micromonospora sp. Piece 2. 7. Hypha and spores. DIC. ZS. 8. Hyphae, sporophores with terminal spores (blue arrow), possible endosporulation (red arrow). DIC. ZS. 9, 10. Scopaeopsis verticillata gen. sp. nov. Piece 2. IGM-LPB 1112. 9. Overall view. The holotype is above (green arrow). The red arrows show different other mycelia of Scopaeopsis veticillata, at different stages of development. The blue arrow, another actinomycete. BF. ZS. 10. As for Figure 4.9, detail. Holotype. Figure 4.10 is turned upside down with respect to Figure 4.9. The sinuous filament on the right belongs to another species. BF. ZS. 
mycelium (Figure 4.5, arrow). As previously observed in the amber containing Thermomonosporopsis waggoneri, the tufts of fertile or sterile filaments are often surrounded by a spherical or umbrella-lake halo (Breton, 2010).

Differences with the other taxa. In Thermomonosporopsis waggoneri, the sporophores are spherical, have a limited extension, and are to be found in both mycelia. In $T$. tenuis, the coloured mycelium is light-coloured, and the sporophores are small $(4 \mu \mathrm{m})$ but can extend as a cylinder of $15 \mu \mathrm{m}$ long along the axis. Another taxon, Cardonia stellata Breton, Bilotte and Eychenne, 2013 which is described from a Campanian amber of the Ariège district (South France) (Breton et al., 2013) has branching roughly similar to $T$. chiapasensis, but the diameter of hyphae is $0.4-0.6 \mu \mathrm{m}$, and it is devoid of the compact sporophore characteristic of the genus Thermomonosporopsis.

Geographical and stratigraphic distribution. These data are restricted to the material described herein: Miocene amber of Chiapas, Mexico.

\section{? Group "Maduromycetes" sensu Goodfellow and Cross, 1984 \\ ? Streptosporangium Couch, 1955 \\ ? Streptosporangium sp. \\ Figure 4.6}

Material. Amber piece 2, together with the fungal mycelium C (see below).

Description. A light coloured, branched filament, $1 \mu \mathrm{m}$ wide, locally taphonomically reduced to $0.3 \mu \mathrm{m}$, bears six spherical sporangia, $10-15 \mu \mathrm{m}$ in diameter, with or without a preserved wall. Five are empty, one contains spores 0.4 $\mu \mathrm{m}$ in diameter, and confuse filaments.

Discussion. This confused pattern of filaments evokes the spore-forming filaments within the sporangia of the living genus Streptosporangium Couch, 1955, hence the taxonomic assignation. Therefore, our material could as well be assigned to the fossil genus Streptosporangiopsis Waggoner, 1994. The poor preservation of our material does not provide arguments to help decide.

Geographical and stratigraphic distribution. These data are restricted to the material described herein: Miocene amber of Chiapas, Mexico.

\section{Group “Actinoplanetes" sensu Nonomura and Tagaki, 1977 \\ ? Micromonospora Ørskov, 1923 ? Micromonospora sp.}

Figure 4.7, 4.8

Material. Amber piece 2, together with the fungal mycelium C (see below). ?Amber piece 2, together with the fungal mycelium $\mathrm{D}$ (see below).

Description. This actinomycete shows branched filaments, $0.5 \mu \mathrm{m}$ (?) in diameter (the question mark is due to the very poor preservation), with single or branched sporophores $0.2-0.3 \mu \mathrm{m}$ in diameter, bearing terminal spores $0.5 \mu \mathrm{m}$. The second filament shows locally possible endospores (Figure 4.8, black arrows).

Discussion. The only feature useful for the identification of such an actinomycete is the morphology of the sporophores and the spores, but it could as well belong to the genus Thermomonospora. The poor preservation, and the sole morphological characters available do not allow a more precise placement.

Geographical and stratigraphic distribution. These data are restricted to the material described herein: Miocene amber of Chiapas, Mexico.

Actinomycetales incertae sedis Morpho-genus Scopaeopsis gen. nov.

Etymology. Latin scopae, arum (noun fem. pl.): swab, bottle-brush. The suffix -opsis denotes a resemblance or an appearance. The sight of this bacterium evokes a swab, or a cylindrical pipe-brush or bottle-brush. Gender feminine.

Type species. Scopaeopsis verticillata, sp. nov. by monotypy.

Diagnosis. Along a rectilinear main axis $1-2 \mu \mathrm{m}$ thick, verticils of much thinner branched filaments are regularly arranged. Verticils build up cylindrical clumps, ca. twice shorter than wide, and separated from one another by intervals as long as or a bit shorter than the clumps (Figure 4.10). The main axis is rarely branched (Figure 4.9). The overall shape is a long cylinder, approximately a constant diameter. The diameter of the colonies ranges from 5 to 40 $\mu \mathrm{m}$. The cylindrical clumps are more or less closely packed.

Differences with other taxa. Many actinomycetes, for instance in the genus Streptoverticillum, have a verticillate structure. None displays such dense and regular verticils. The organization of this actinomycete, with regular verticillate forming very dense clumps along a main axis is thus very distinctive and no other known genus, among fossil or living actinomycetes, shares such morphology.

Geographical and stratigraphic distribution. These data are restricted to the material described herein: Miocene amber of Chiapas, Mexico.

Morpho-species Scopaeopsis verticillata sp. nov. Figure 4.9, 4.10

Etymology. Verticillata (latin): verticillate.

Holotype. The specimen figured as Figure 4.9 (above, green arrow) and 4.10, IGM-LPB 1112.

Geographical and stratigraphic origin of the holotype. Amber of Totolapa, Chiapas, Mexico. Miocene.

Material. Amber piece 2.

Diagnosis. As for the genus.

Description. Only one occurrence of this curious taxon has been encountered, in one flake of amber piece 2. In an area of $200 \times 100 \mu \mathrm{m}$, five main axes run sub-parallel (Figure 4.9). The diameter of the colonies ranges from 6 to 
$40 \mu \mathrm{m}$. The overall impression is that of different stages of development. Unfortunately, these microfossils lie rather deeply in amber, so that it is difficult to get a precise picture, especially of the verticils. Notably, it is not possible to specify if these verticils are or bear reproductive structures. Among the colonies, a sinuous filament $2 \mu \mathrm{m}$ thick seems to belong to a distinct micro-organism.

Discussion. Scopaeopsis verticillata remains unplaced at the family level because the character "verticillate hyphae" can be found in several families and is not, by itself, a decisive character (Holt, 1989; Miyadoh, 1997).

\section{Morpho-genus A, morpho-species A}

2009d Dichotomous branching filaments, microcolonies of actinomycetes: Girard et al., p. 155, fig. 1 A-C.

2010 Actinomycètes de type A: Girard, p. 75-76, Fig. IV-7.

2012 Actinomycètes de type A, Girard, 2010: Breton, p. 69, Fig. 116.

Figure 5.1-5.5

Material. Numerous colonies in the periphery of amber pieces $1,5 \mathrm{~A}, 5 \mathrm{~B}, 7$ and 8 .

Description. Colonies small $(3-20 \mu \mathrm{m})$ and rounded (Figure 5.1-5.5). Filaments $0.3-0.5 \mu \mathrm{m}$ in diameter, black or dull coloured, regularly $1-4$ times dichotomously branched at $60^{\circ}$. Branches short. Tips of branches may be enlarged, ovally rounded (Figure 5.3). These colonies can release first linear or branched fragments, and then abundant cocci-like spores $(0.5-0.8 \mu \mathrm{m}$ in diameter $)$ produced by thallus fragmentation (Figure 5.1, 5.4). As previously noticed by Girard (2010, fig. IV-7C) and Girard et al. (2009d, fig. 1B), these colonies can become coalescent and build up a thin cortical layer, in which single colonies become indistinct. We confirm Girard's observation (2010) that the colonies are often lined up.

Discussion. According to some observations (Figure 5.2), the lining up of the colonies seems to proceed from their growth from an early straight stolonal filament, $0.3 \mu \mathrm{m}$ in diameter (Figure 5.2, red arrow), which disappears later between the colonies when they come to maturity.

We leave this species of actinomycetes in open nomenclature. Though its overall morphology seems distinctive, this is not enough to allow a confident placement within the actinomycetes families. Admittedly, the sporulation by thallus fragmentation provides a reproductive structure, but such a character is shared by many actinomycetes in distinct families, and we must wait for better material before naming and placing this distinctive species.

Geographical and stratigraphic distribution. This morpho-species is known in mid-Cretaceous amber from France, and in Miocene amber from Mexico.

Bacterium incertae sedis

Figure 5.6-5.8
Material. Amber pieces and preparations 6B and 8.

Description. A chain up to $285 \mu \mathrm{m}$ long of uniseriate cells (Figure 5.6), $0.7-1.0 \mu \mathrm{m}$ wide, $2.0-3.0-4.0 \mu \mathrm{m}$ long (once $6.0 \mu \mathrm{m}$ long), light coloured, made up of several dozens of cells at most, straight or slightly flexuous, devoid of sheath, false branching rare (Figure 5.6, 5.7), showing in some cells two to four rounded endospores $0.8 \mu \mathrm{m}$ in diameter (Figure 5.6, 5.8, red arrow). Diameter of the cells $0.7-1.0 \mu \mathrm{m}$. When a transversal division of the cells occurs, it includes a dozen neighbouring cells, and then, cells are twice shorter and can be nearly square.

Discussion. Though distinctive in our material, the morphology of this bacterial species is poor and does not give any clue for its systematic placement. We thus leave it in open nomenclature.

Geographical and stratigraphic distribution. These data are restricted to the material described herein: Miocene amber of Chiapas, Mexico.

\section{Fungi incertae sedis}

Figures 5.9, 5.10, 6.1-6.3

None of the fungal mycelia display features which could allow a confident taxonomic placement.

\section{Fungus incertae sedis A}

Amber piece 4 shows branched, (1) $1.5-2.0 \mu \mathrm{m}$ wide, (2) $3.0-4.0 \mu \mathrm{m}$ wide, not septate hyphae, associated with decayed vegetal matter (Figure 5.9). [These measures are approximate because the thickness of the amber flake forbad the use of high magnification lenses].

\section{Fungus incertae sedis B}

In the same amber piece 4 and in the same amber flake, wider $(5 \mu \mathrm{m})$ irregularly septate hyphae have cells 5 times longer than wide, or more (Figure 6.1, red arrow). These hyphae have locally a black, granulose content. Amber around these granulose filaments is darker, but without a neat limit and without granulations, so that it cannot be considered a sheath. Granulose filaments is a taphonomic variation of the septate hyphae.

\section{Fungus incertae sedis $\mathrm{C}$}

Besides rare and isolated fragments of hyphae carried along by the resin flow, amber piece 2 has yielded two mycelial networks. The first one develops over more than 400 $\mu \mathrm{m}$ (Figure 5.10). The hyphae, $1-2 \mu \mathrm{m}$ in diameter, are light coloured, septate, branched, with a wall locally granulose. The hyphae are somewhat crumpled, poorly preserved. They are interspersed with actinomycete filaments (cf. ? Streptosporangium sp. and ? Micromonospora sp. above). 

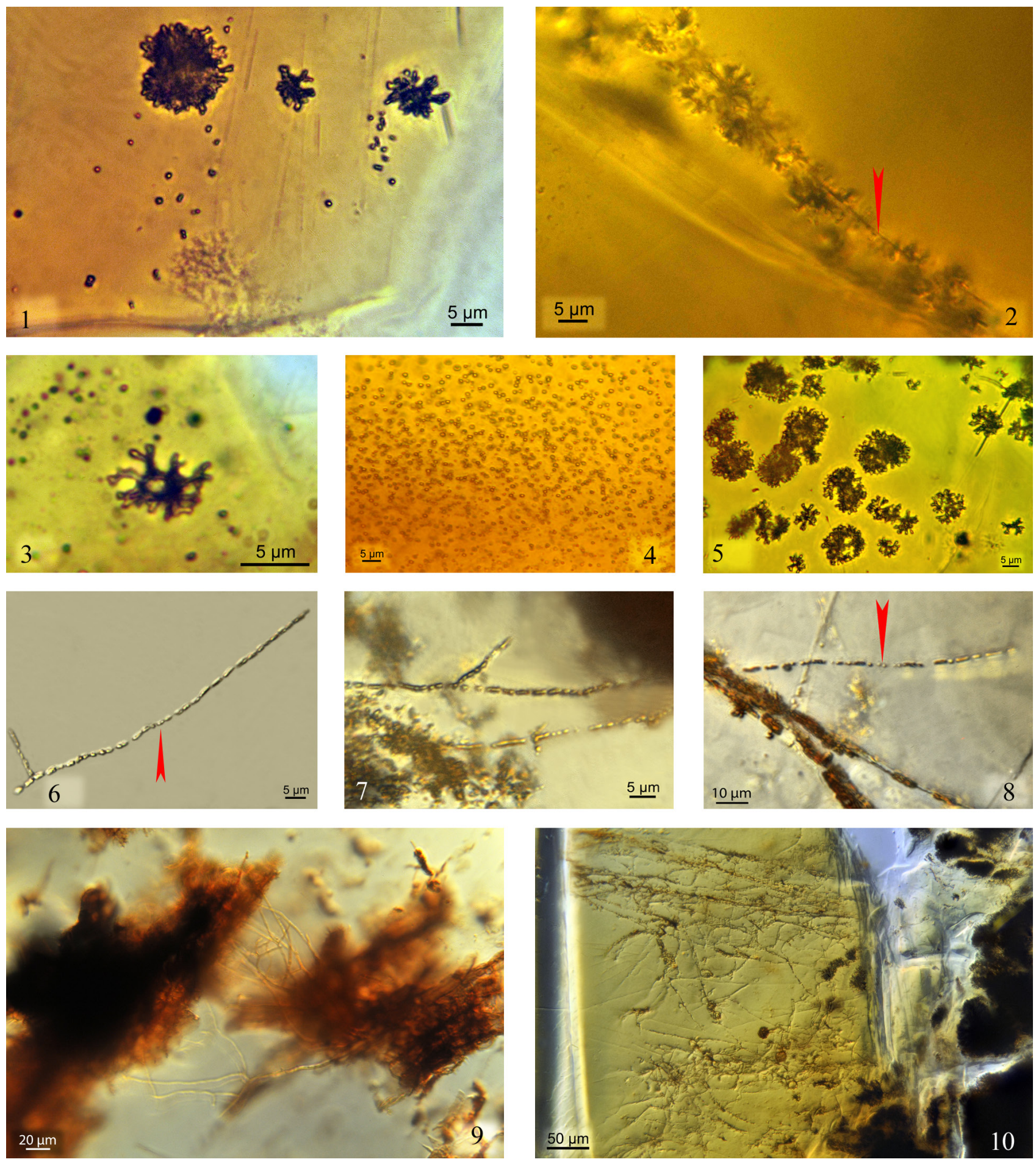

Figure 5. 1-5. Actinomycete Genus A species A. 1. Piece 8. Three colonies. Release of coccoid spores. BF. ZS. 2. Piece A. Colonies growing from an early straight stolonal filament (red arrow). BF. ZS. 3. Piece A. Small colony with ovally rounded branches tips, and coccoid spores. BF. ZS. 4. Piece 5A. Coccoid spores dispersed in amber. FC. ZS. 5. Piece 5B. Colonies at different stages of development. FC. ZS. 6-8. Bacterium incertae sedis. 6. Piece 6B. A chain of uniseriate cells, one perpendicular false branching. Red arrow: endospores. DIC. ZS. 7. Piece 6B. A chain of uniseriate cells, one perpendicular false branching. DIC. ZS. 8. Piece 8. A chain of uniseriate cells, false branching. Red arrow: endospores. DIC. ZS. 9, 10. Fungi incertae sedis. 9. Piece 4. Fungal filament A on decaying vegetal matter. DIC. Mosa. 10. Piece 2. Fungal mycelium C. DIC. ZS. 


\section{Fungus incertae sedis D}

In amber piece 2 , but in a different flake taken perpendicularly from the surface, a mycelium developed. From a superficial and very dense layer (Figure 6.2, $6.3)$, branched brown hyphae, $2 \mu \mathrm{m}$ in diameter, slightly crumpled, apparently septate, grew centripetally over 300 $\mu \mathrm{m}$. Interspersed actinomycetes (? Micromonospora sp.) are few.

Discussion. The presence of four morphologically distinct mycelia demonstrate a good diversity among the fungi fossilized in the Totolapa amber. Therefore, their state of preservation, and the lack of reproductive structure forbid a more precise taxonomic placement.

\section{Micro-inclusions incertae sedis}

Figure 6.4-6.7

Several micro-inclusions of incertae sedis are associated with the mycelium network $C$ (Figure 6.4-6.7).

A vermiform J-shaped brown structure, limited by a neat membrane, with confuse granular content, measures $40 \times 7 \mu \mathrm{m}$. It might be a protist, or a fragment of decaying biological matter (Figure 6.5).

A rounded cell, $8 \mu \mathrm{m}$ in diameter, with a thick wall and a (nuclear?) central round organite, $3 \mu \mathrm{m}$ in diameter, surrounded by granulations, is interpreted as a cyst cell or a spore (Figure 6.7).

Two brown bags of $50 \mu \mathrm{m}$ wide have a crumpled wall. Both seem empty, and are thus presumed to be sporangia walls after the release of the spores (Figure 6.4, 6.6).

\section{Discussion}

\subsection{Amber and the pyroclastic sediments}

A very puzzling point is the position of the amber pieces at the base of pyroclastic beds deposited during an ash-flow event. Amber, when heated, first softens (between $150^{\circ} \mathrm{C}$ and $250^{\circ} \mathrm{C}$ according to Lacroix, 1910), melts when the temperature increases and then, can burn when oxygen is available. The studied amber pieces from Totolapa do not show any evidence of heating. Their gangue is not ash or pyroclastic sediment, but a slightly clayey gypsum sand with tiny wood fragments. The pyrite contained in some of the amber pieces is not an argument for the lack of oxygen at the time of reworking, since pyrite was embedded or formed when the resin was fluid. New field studies are thus needed to decide if a peculiar context (for instance presence of water) protected the amber pieces from excessive heating by the ash flow. Anyhow, the good state of conservation of the micro-organisms within the amber demonstrates that the impact of heat (if any) was weak or nil.

\subsection{Taphonomy of the micro-organisms}

Recent works highlighted the generality of an early colonization of resin exudates, either fossil or modern, by filamentous micro-organisms such as actinobacteria, cyanobacteria, other bacteria (e.g. sheathed bacteria) and fungi (Rikkinen and Poinar, 2000; Rikkinen, 2003; Brasier et al., 2009; Beimforde and Schmidt, 2011; Breton, 2011). Compared with taphonomic processes involved for other marine or continental fossils, this leads to a very particular taphonomic process: resinicolous microbes are able to grow within the resin (Schmidt and Schäfer, 2005; Schmidt, 2006; Beimforde and Schmidt, 2011). The growth stops when the resin hardens. Large areas of the surface of the exudate can be colonized, either by a network of filaments parallel to the surface, or growing centripetally (filamentous bacteria and fungi) or by a turf of clumps with a centripetal growth (some actinomycetes) (Breton, 2011, 2012). The early colonization of fossil resin exudates by such filamentous micro-organisms has also been described, for instance in Cretaceous or Eocene amber (Girard et al., 2009a,d; Breton, 2010, 2011; Girard, 2010; Saint Martin et al., 2012; Breton, 2012; Saint Martin et al., 2013; Breton et al., 2013). Among the taxa described herein, Melanothrix mexicana, Thermomonosporopsis chiapasensis, the actinomycete gen. A sp. A, and the fungal mycelium D are certainly early colonizers of the resin exudates. All, but the fungus, are present in at least three amber pieces. Scopaeopsis verticillata is certainly not a colonizer, but was trapped by the flow of resin. The fungal mycelium $\mathrm{C}$, and the associate actinomycetes cf. ?Streptosporangium $\mathrm{sp}$. and ?Micromonospora sp. are certainly not resin colonizers, because their filaments are elongated in the resin flow, and are very poorly preserved: they are thought to have begun decaying before trapping. Even though filaments grown in resin are always "clean", some of these filaments are "dirty", and have been trapped together with dirt. The fungal mycelia A have certainly been trapped together with the vegetal fragments to which they are attached; as they are not elongated, the resin in which they have been trapped was thought to be very fluid. Compared with taxa present in three amber pieces, the fungal mycelia $\mathrm{A}$ and $\mathrm{C}$, and Scopaeopsis verticillata, restricted to one amber piece, are thought to represent sporadic taxa. We think they were present on the bark of the tree. The status of the bacterium incertae sedis (trapped vs. colonizer) remains uncertain. The comparison with the microorganisms, mainly fungi, of modern conifer resin exudates indicates that the amber pieces $1-3$ and $5-$ 8 of Totolapa amber were trunk exudates. The resinicolous micro-organisms were inoculated by anemochoric spores, or by an inoculum present on the bark. 

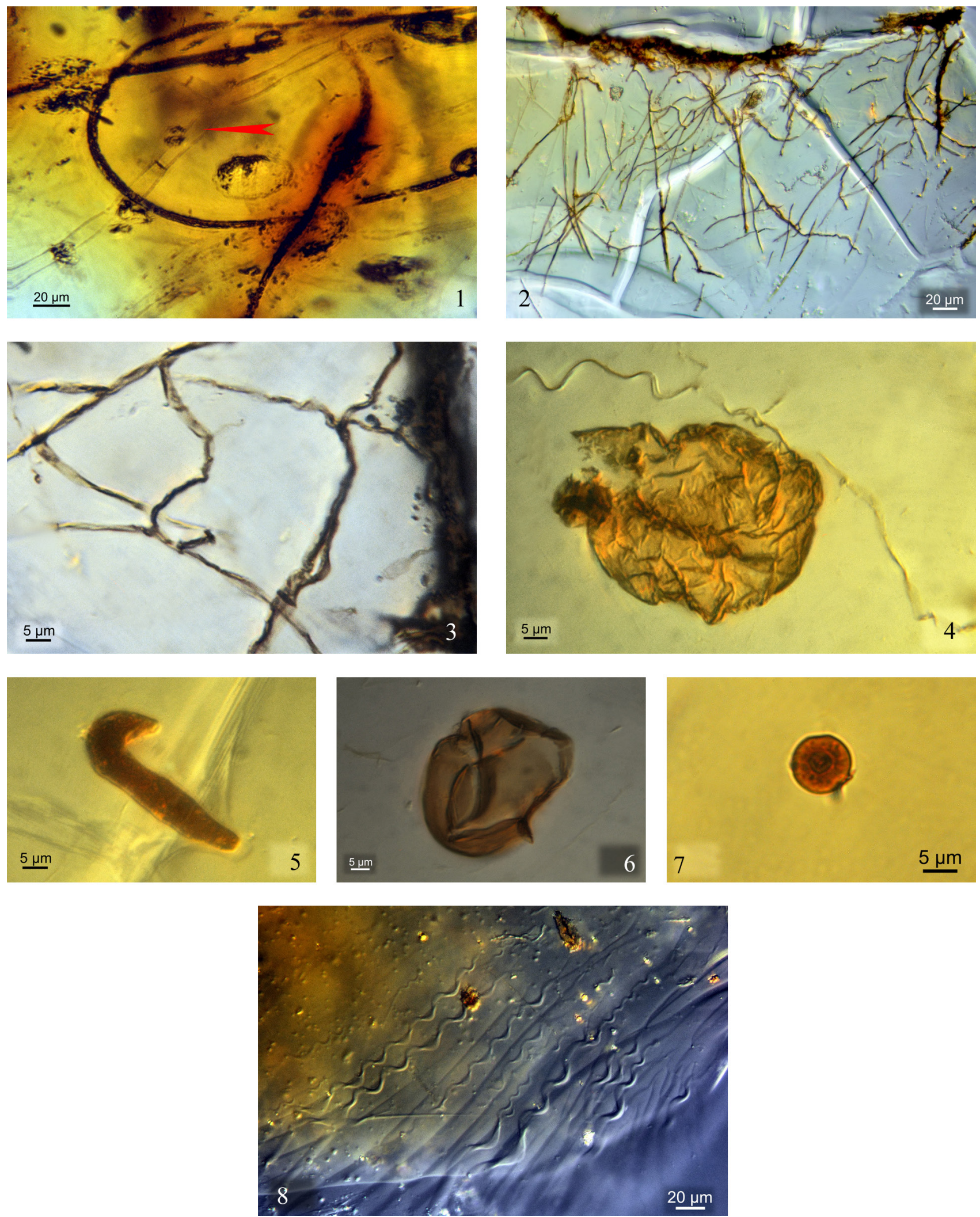

Figure 6. 1-3. Fungi incertae sedis. 1. Piece 4. Fungal mycelium B: clear, irregularly septate hyphae (red arrow), and hyphae with a black, granulose content surrounded by darker amber. BF. ZS. 2. Piece 2. Fungal mycelium D, issued from a superficial dense layer (above). DIC. ZS. 3. Piece 2. Detail of Figure 6.2. Dense superficial layer on the right of the picture. Note the rather crumpled hyphae. DIC. ZS. 4-6. Micro-inclusions incertae sedis. 4. Sporangium wall after the release of the spores. The sinuous filament belongs to an actinomycete. DIC. ZS. 5. Piece 2. J- shaped micro-inclusions. Protist? Or decaying matter? DIC. ZS. 6. Sporangium wall after the release of the spores. DIC. ZS. 7. Piece 2. Rounded cyst cell or spore. DIC.8. Piece 2. Pseudo-fossil: break surface with a sinusoidal pattern. DIC. ZS. 


\subsection{Systematics and distribution}

Our first aim was to describe the fossil microbes of Totolapa amber. We have described and named explicit morpho-taxa only because morphological characters were available. We have, when possible, included these taxa in higher groups of the classification (e.g. Burkholderiales or Actinomycetales and their families or "groups") because they display characteristic morphologies such as the sheath of Burkholderiales or the branching of Actinomycetales. Such morpho-taxa should not be used for phylogenetic purposes. As highlighted by Girard and Adl (2011), the poor morphology of micro-organisms leads to the misleading conclusion that fossil and extant taxa are similar, and thus are in morphological stasis. Dealing with microorganisms, especially prokaryotes, paleontological studies are ineffective for phylogenetic consideration.

Among the taxa recognized here, five are new, and four are named. If their known occurrence is restricted to the Miocene amber of Chiapas, new studies will be necessary to decide whether their repartition is much larger or not. Thermomonosporopsis chiapasensis belongs to a morphological category of actinomycetes also known in Campanian and Eocene of France (Breton, 2012; Breton et al., 2013), and the actinomycete gen. A sp. A is also known from the French Cenomanian ambers (Girard, 2010).

\subsection{Paleoenvironment}

Besides the amber pieces studied here, other Miocene ambers from Chiapas (Mexico) contain aerial or aquatic animals and plants (Serrano et al., 2007; Vega et al., 2009a, b). The paleoenvironment of resin secretion is a near shore forest or mangrove of Hymenea; the amber pieces sometimes fossilize biota from an aerial environment, either as colonizing organisms or trapped organisms (bark exudates), and sometimes biota from a freshwater environment (exudates which flowed within water collection). The course to the place of deposition after solidification of the resin was short because the resin pieces were not abraded since they still preserve the peripheral fungi and bacteria.

\section{Conclusion}

Early colonization of resin exudates by microbes is attested at least since the Mid-Cretaceous up to now. Bacterial and fungal contents of these microfloras is exemplified by Mid-Cretaceous, Upper Cretaceous, and Eocene ambers, and by modern resin. Studied Mid-Cretaceous colonizers of resins were mainly cyanobacteria and sheathed bacteria (Breton, 2007; Girard, 2010, Girard et al., 2009a); Upper Cretaceous and Eocene were actinomycetes (Breton, 2010; 2012, Breton et al., 2013; Saint Martin et al., 2012; 2013), whilst modern resins are largely settled by fungi (Breton,
2011; 2012). The Miocene amber of Totolapa provides us insight on Miocene settlers, until now an unexplored period. But we must keep in mind that resin-producing trees, climate and environment do play a role, and thus that new studies are expected.

\section{Acknowledgments}

Marco A. Coutiño (Museo de Paleontología de Chiapas) and Torrey Nyborg (Loma Linda University, Californa, USA) helped during fieldwork in Totolapa and reviewed the manuscript for style and grammar corrections. Our sincere gratitude to Laura Luna (Instituto de Geología, UNAM) for her assistance with location and geologic map. Support from the Posgrado en Ciencias de La Tierra is highly appreciated. We gratefully thank Dr. Simona Saint Martin (Muséum National d'Histoire Naturelle, Paris) and César Fernando Aguilar Ramírez (Instituto de Geología, UNAM) for their constructive review and valuable comments on our manuscript.

\section{References}

Azar, D., Nel, A., Coty, D., Garrouste, R., 2010, The second fossil ceratocombid bug from the Miocene amber of Chiapas (Mexico) (Hemiptera: Ceratocombidae): Annales de la Société Entomologique de France (Nouvelle série), 46, 1-2, 100-102.

Beimforde, C., Schmidt, A.R., 2011, Microbes in resinous habitats: a compilation from modern and fossil resins, in Retner, J. Queric, V., Arp, G. (eds.), Advances in Stromatolite Geobiology: Lectures Notes in Earth Sciences, Berlin, Springer Verlag, 391-407.

Blunck, G., 1929, Bakterieneinschlüsse im Bernstein: Centrelblatt für Mineralogie, Geologie und Paläontologie, 11, 554-555.

Brasier, M., Cotton, L., Yenney, Y., 2009, First report of amber with spider webs and microbial inclusions from the earliest Cretaceous ( $c a$. $140 \mathrm{Ma}$ ) of Hastings, Sussex: Journal of the Geological Society. London 166, 989-997.

Breton, G., 2007, La bioaccumulation de microorganismes dans l'ambre: analyse comparée d'un ambre cénomanien et d'un ambre sparnacien, et de leurs tapis algaires et bactériens: Comptes Rendus Palevol, $6,125-133$.

Breton, G., 2010, Les Actinomycetales de l'ambre sparnacien des Corbières (Aude, France): taphonomie et diversité: Annales de la Société Géologique du Nord, Lille 17 (2è sér.), 3-22.

Breton, G., 2011, L'ambre, un milieu de culture fossilisé [in résumés des communications du congrès 2011 de l'Association Paléontologique Française, Elbeuf, 19-21 mai 2011]: Bulletin de la Société d'étude des Sciences Naturelles d'Elbeuf 2è trim, 2011, 28-29.

Breton, G., 2012, L'ambre des Corbières (Aude-France): SESA, Carcassonne, 96 pp, [ISBN 978-2-9531120-3].

Breton, G., Bilotte, M., Eychenne, G., 2013, L'ambre campanien du Mas d'Azil (Ariège, France): gisement, microinclusions, taphonomie. Annales de Paléontologie, http://dx.doi.org/10.1016/j. annpal.2013.06.001

Breton, G., Gauthier, C., Vizcaïno, D., 1999, Land and freshwater microflora in a Sparnacian amber from the Corbières (South France): first observations: Estudios del Museo de Ciencias Naturales de Alava, 14 (núm. espc. 2), 161-166.

Breton, G., Tostain, F., 2005, Les microorganismes de l'ambre cénomanien d'Ecommoy (Sarthe, France): Comptes Rendus Palevol, 4, 31-46.

Bryant, D.D., 1983, A recently discovered amber source near Totolapa, Chiapas, Mexico: American Antiquity, 48, 354-357. 
Buchanan, R.E., 1917, Studies in the nomenclature and classification of bacteria, II: The primary subdivisions of the Schizomycetes: Journal of Bacteriology, 2, 155-164.

Couch, J.N., 1955, A new genus and family of the Actinomycetales, with a revision of the genus Actinoplanes: Journal of the Elisha Mitchell Scientific Society 71, 148-155.

Damon, P., Montesinos, E., 1978, Late Cenozoic volcanism and metallogenesis over an active Benioff Zone in Chiapas, Mexico: Arizona Geological Society Digest, 11, 155-168.

Durán-Ruiz, C., Riquelme, F., Coutiño-José, M., Carbot-Chanona, G., Castaño-Meneses, G., Ramos-Arias, M., 2013, Ants from the Miocene Totolapa amber (Chiapas, México), with the first record of the genus Forelius (Hymenoptera, Formicidae): Canadian Journal of Earth Sciences, 50, 5, 495-502.

Galippe, M.G., 1920, Recherches sur la résistance des microzymas à l'action du temps et à leur survivance dans l'ambre: Comptes rendus de l'Académie des Sciences, Paris, 170, 856-858.

Garrity, G.M., Bell J.A., Lilburn T., 2005, Order I. Burkholderiales ord. nov. in Brenner, D.J., Krieg, Staley, N.R., Garrity, J.T. (eds.), Bergey's Manual of Systematic Bacteriology, second edition, vol. 2 (The Proteobacteria), part C (The Alpha-, Beta-, Delta-, and Epsilonproteobacteria), Springer, New York, 2005, p. 575.

Girard, V., 2009, Evidence of Scenedesmaceae (Chlorophyta) from a 100 million-year-old amber, in Néraudeau, D., Perrichot, V. (eds.), Studies on middle Cretaceous deposits from Southwestern France, Geodiversitas, 31, 145-151.

Girard, V., 2010, Microcénoses des ambres médio-crétacés français. Taphonomie, systématique, paléoécologie et reconstitution du paléoenvironnement: Ph.D. dissertation, Université de Rennes, France, $294 \mathrm{p}$.

Girard, V., 2012, Fossil Amoebae (Hemiarcherellidae fam. nov.) from Albian (Cretaceous) amber of France: Palaeontology, 55, 3, 653-659.

Girard, V., Adl, S.M., 2011, Amber microfossils: On the validity of the species concept: Comptes Rendus Palevol, 10, 189-200.

Girard, V., Breton, G., Brient, L., Néraudeau, D., 2009a, Sheathed prokaryotic filaments, major components of mid-Cretaceous French amber microcoenosis: Journal of Paleolimnology, 42, 437-447.

Girard, V., Néraudeau, D., Adl, S.M., Breton, G., 2011, Protist-like inclusions in amber as evidenced by Charentes amber: European Journal of Protistology, 47, 59-66.

Girard, V., Néraudeau, D., Breton, G., Saint Martin, S., Saint Martin, J.-P., 2009 b, Contamination of amber samples by recent microorganisms and remediation evidenced by mid-Cretaceous amber of France: Geomicrobiology Journal, 26, 1, 21-30.

Girard, V., Saint Martin, S., Saint Martin, J.-P., Schmidt, A.R., Struwe, S., Perrichot, V., Breton, G., Néraudeau, D., 2009c, Exceptional preservation of marine diatoms in Upper Albian amber: Geology, $37,1,83-86$

Girard, V., Schmidt, A.R., Struwe, S., Perrichot, V., Breton, G., Néraudeau, D., 2009d, Taphonomy and palaeoecology of mid-Cretaceous French amber-preserved microorganisms from South-western France, in Néraudeau, D., Perrichot, V., (eds), Studies on middle Cretaceous deposits from southwestern France, Geodiversitas, 31, 153-162.

Goodfellow, M., Cross, T., 1984, Classification, in Goodfellow, M., Mordarsky, M., Williams, S.T. (eds.), The Biology of Actinomycetes: Academic Press, London, p. 7-164.

Göppert, H.R., Berendt, G.C., 1845, Der Bernstein und die in ihm befindlichen Planzenreste des Vorwelt, in Berendt, G.C. (ed.), Die im Bernstein befindlichen organischen Reste der Vorwelt, Berlin: Nicolaische Buchhandlung, 6-126.

Göppert, H.R., Menge, A., 1883, Die Flora des Bernsteins und ihre Beziehungen zur Flora der Tertiärformation und der Gegenwart: Volume I, Danzig, $140 \mathrm{p}$.

Häntzschel, W., 1975, Part W Miscellanea, supplement 1: Trace fossils and problematica, in Moore, C., (ed.), Treatise on Invertebrate Paleontology, Boulder, Colorado: The Geological Society of America and The University of Kansas, $269 \mathrm{pp}$.

Hofmann, H.J., 1971, Precambrian fossils, pseudofossils and problematica in Canada: Geological Survey of Canada Bulletin, 189, 146 p.

Holt, J.G., 1989, Bergey's manual of systematic bacteriology: Volume 4. Williams and Wilkins, Baltimore, U.S.A., 2299-2648.

Kohring, R., 1995, Fossile Bakterien und Pilzsporen aus dem Baltischen Bernstein: Neues Jahrbuch für Geologie und Paläontologie. Monatshefte, 1995, 6, 321-335.

Lacroix, A., 1910 (réed. 1977), Minéralogie de la France et de ses anciens territoires d'Outre-mer. Tome quatrième, Librairie du Muséum, Paris (réed.), 1-923.

Miyadoh, S., 1997, Morphology and phylogeny of Actinomycetes, in Miyadoh, S. (editor-in-chief), Atlas of Actinomycetes: The Society for Actinomycetes Japan (publ.), Asakura Publishing Company, 198-199.

Mora, J.C., Jaimes-Viera, M.C., Garduño-Monroy, V.H., Layer, P., Pompa-Mera, V., Godinez, L., 2007, Geology and geochemistry characteristics of the Chiapanecan Volcanic Arc (Central Area), Chiapas Mexico: Journal of Volcanology and Geothermal Research, $162,43-72$.

Mora, J.C., Layer, P.W., Jaimes-Viera, M.C., 2012, New ${ }^{40} \mathrm{Ar} /{ }^{39} \mathrm{Ar}$ ages from the Central Part of the Chiapanecan Volcanic Arc, Chiapas, México: Geofísica Internacional, 51, 1, 39-49.

Nonomura, H., Tagaki, S., 1977, Distribution of actinoplanetes in soils of Japan: Journal of Fermentation Technology, 55, 423-428.

Ørskov, J., 1923, Investigations into the morphology of the Ray Fungi: Lewin and Munksgaard, Copenhagen, Denmark, $171 \mathrm{p}$.

Perrilliat, M.C., Vega, F.J., Coutiño, M.A., 2010, Miocene Mollusks from the Simojovel area in Chiapas, southwestern Mexico: Journal of South American Earth Sciences, 30, 111-119.

Poinar, G., 1999, Cenozoic fauna and flora in amber: Estudios del Museo de Ciencias Naturales de Álava, 14, n. esp. 2, 151-154.

Poinar, G.O. Jr., 1992, Life in amber: Stanford University Press, Stanford. $350 \mathrm{p}$.

Poinar, G.O. Jr., 1994, Fossils in amber: Current Science, 66, 6, 417-420.

Poinar, G.O. Jr., 2003, Coelomycetes in Dominican and Mexican amber: Mycological Research, 107, 117-122.

Poinar, G.O. Jr., Waggoner, B.M., Bauer, U.C., 1993, Terrestrial soft-bodied protists and other micro-organisms in Triassic amber: Science, 259, 222-224.

Poinar, G.O. Jr., Poinar, R., 2005, Fossil evidence of insect pathogens: Journal of Invertebrate Pathology, 89, 243-250.

Rikkinen, J., 2003, New resinicolous ascomycetes from beaver scars in western North America: Annales Botanici Fennici 40, 443-450.

Rikkinen, J., Poinar G.O., Jr., 2000, A new species of resinicolous Chaenothecopsis (Mycocaliciaceae, Ascomycota) from 20 million year old Bitterfeld amber, with remarks on the biology of resinicolous fungi: Mycological Research 104, 7-15.

Saint Martin, S., Saint Martin, J.-P., Girard, V., Grosheny, D., Néraudeau, D., 2012, Filamentous micro-organisms in Upper Cretaceous amber (Martigues, France): Cretaceous Research, 35, 217-229.

Saint Martin, S., Saint Martin, J.-P., Girard, V., Néraudeau, D., 2013, Organismes filamenteux de l'ambre du Santonien de Belcodène (Bouches-du-Rhône, France): Annales de Paléontologie, http:// dx.doi.org/10.1016/j.annpal.2013.03.001.

Schmidt, A.R., 2006, Microorganisms and microcoenoses of Cretaceous forests - new insight from amber, in Barrett, M.P., Evans, S.E. (eds.), Ninth International Symposium on Mesozoic Terrestrial Ecosystems and Biota: The Natural History Museum, London, 110-113.

Schmidt, A.R., Schäfer, U., 2005, Leptotrichites resinatus new genus and species: a fossil sheathed bacterium in alpine Cretaceous amber: Journal of Paleontology, 79, 175-184.

Schmidt, A.R., Dilcher, D.J., 2007, Aquatic organisms as amber inclusions and examples from a modern swamp forest: Proceedings of the National Academy of Sciences of the United States of America, 104, 16581-16585.

Schmidt, A.R., Schönborn, W., Schäfer, U., 2004, Diverse fossil amoebae in German Mesozoic amber: Paleontology, 47, 185-197.

Schmidt, A.R., Ragazzi, E., Coppelloti, O., Roghi, G., 2006, A microworld in Triassic amber: Nature, 444, 835 
Schmidt, A.R., Ragazzi, E., Coppelloti, O., Roghi, G., 2007, Microorganisms in Triassic amber from Italy: FossilsX3, III World Congress on Amber Inclusions, Abstract Book, 152.

Schmidt, A.R., Dörfelt, H., Perrichot, V., 2008, Paleoanellus dimorphus gen. et sp. nov. (Deuteromycota): a Cretaceous predatory fungus: American Journal of Botany, 95, 1328-1334.

Serrano, M.L., Vega, F.J., Coutiño, M.A., 2007, Terrestrial isopods included in Miocene amber from Chiapas: Geological Society of America, Abstracts with Programs, 39, 6, 76.

Servicio Geológico Mexicano, 2005, Carta Geológico-Minera, Tuxtla Gutiérrez E15-11, escala 1:250000: INEGI, México, DF.

Solórzano-Kraemer, M.M., 2007, Systematic, palaeoecology, and palaeobiogeography of the insect fauna from Mexican amber: Palaeontographica, A, 282, 1-133.

Solórzano-Kraemer, M.M., 2010, Mexican Amber, in Penney, D. (ed.), Biodiversity of fossils in amber from the major world deposits, Manchester, UK: Siri Scientific Press, 42-56.

Stackebrandt, E., Rainey, F.A., Ward-Rainey, N.L., 1997, Proposal for a new hierarchic classification system, Actinobacteria, classis nov. International Journal of Systematic Bacteriology, 47, 2, 479-491.

Vega, F.J., Zúñiga, L., Pimentel, F., 2009a, First formal report of a crab in amber from the Miocene of Chiapas and other uncommon Crustacea: Geological Society of America, Abstracts with Programs, 41, 7, 631.

Vega, F.J., Nyborg, T., Coutiño, M., Hernández-Monzón, O., 2009b, Neogene Crustacea from southeastern Mexico: Bulletin of the Mizunami Fossil Museum, 35, 51-69.
Veiga-Crespo, P., Blasco, L., Poza, M., Villa, T.G., 2007, Putative ancient microorganisms from amber nuggets: International microbiology, 10, 117-122.

Waggoner, B.M., 1993, Fossil Actinomycetes and other Bacteria in Eocene amber from Washington State, U.S.A.: Tertiary Research, $14,4,155-160$.

Waggoner, B.M., 1994a, Fossil micro-organisms from the Upper Cretaceous amber of Mississippi: Review of Palaeobotany and Palynology, 80, 75-84.

Waggoner, B.M., 1994b, Fossil actinomycetes in Eocene-Oligocene Dominican amber: Journal of Paleontology, 68, 398-401.

Waggoner, B.M., 1996, Bacteria and protists from the Middle Cretaceous amber of Ellsworth County, Kansas: Paleobios, 17, 1, 20-26.

Waggoner, B.M., Poinar, G.O. Jr., 1992, A fossil myxomycete Plasmodium from Eocene-Oligocene amber of the Dominican Republic: Journal of Protozoology, 39, 639-642.

Woese, C.R., Kandler, O., Wheelis, M.L., 1990, Towards a natural system of organisms: Proposal for the domains Archaea, Bacteria and Eucarya: Proceedings of the National Academy of Sciences of the United States of America, 87, 4576-4579.

Manuscript received: August 27, 2013

Corrected manuscript received: November 11, 2013.

Manuscript accepted: November 8, 2013. 